\title{
Protection of the Rights of All Migrant Workers and Members of Their Families Within the Albanian Context
}

\author{
Prof. Assoc. Dr. Nejla PEKA \\ Legal expert, Department of Legislation, Monitoring of Programs and Anticorruption, Prime Minister's Office
}

\begin{abstract}
The purpose of this exploratory study is to investigate about the changes in legal framework and the role that legislative measures play in promoting and protecting all the people rights, especially of all migrant workers and members of their families. The study employs a mixed methodology, comprising a review of the legislation, institutional framework, statistics data and some of the relevant literature in the field of international law, regarding the conventions, bilateral agreements and some other documents for promoting and respecting migrant workers' rights. The findings of this study are supported in prior research in analyzing a lot of documents, strategies, prepared by NGO-s and other government institutions. The in-depth analysis of the qualitative data revealed a basic understanding of promoting and protecting migrant workers and members of their families in my country.
\end{abstract}

Keywords: international law, social cohesion, migration, migrant worker, work, education, social protection, promoting and protecting migrant worker's rights, legal framework etc.

\section{Introduction}

In fulfillment of international obligations arising from the conventions on human rights, in which our country is a party, the Albanian institutions have a legal obligation to periodically report on the implementation of the provisions of the United Nations Conventions on the Rights of man, in which our country has signed and ratified. Through reporting, the key is fulfillment of international obligations in the field of human rights, especially the fulfillment of obligations related to the protection and respect of human rights in all aspects of life.

Albania has ratified a number of conventions and international agreements on the protection of human rights, particularly in the field of labor migration, making them part of of domestic legislation. Among them are: the Convention of the International Labour Organization (ILO) No. 97, "Migration for Employment"1, Convention no. 143 "For migrant workers (additional provisions) in 1975", as well as the Council of Europe Convention "On Legal Status of Migrant Workers"2.

One of these conventions is the UN Convention for the Protection of the Rights of All Migrant Workers and Members of Their Families ${ }^{3}$. The entire spirit that permeates this convention relates to the obligation of States Parties, in accordance with international instruments concerning human rights, to respect and ensure to all migrant workers and members of their families within its territory or subject to the jurisdiction their rights under the present Convention 4 .

In all provisions of the Convention is foreseen taking necessary legal, institutional and administrative measures by member states, and they have to follow within the guarantee specific rights identified in the Convention.

\footnotetext{
${ }^{1}$ Ratified with law no.9320, dated 25.11.2004

2 Ratified by Parliament with law no.9555, dated 8.6.2006.

3 This Convention is ratified by Parliament with law no.9703, dated 2.4.2007.

${ }^{4}$ In Article 7 of the Convention stated that: "... States Parties, in accordance with international instruments concerning human rights, undertake to respect and ensure to all migrant workers and members of their families within its territory or subject their jurisdiction, regardless of gender, race, color, language, religion, belief, political or other opinion, national origin, ethnic or social origin, nationality, age, economic status, wealth, marital status, status of birth or other rights Theirs...".
} 


\section{National Report, obligation deriving from the Convention}

Each State Party shall submit to the Committee of Experts of the Convention a report on measures taken on the implementation of the Convention, beginning from the entry into force of this Convention for that State Party 1.

Our country has reported periodically and during the current reporting period on protecting the rights of migrant workers and members of their families, what stands out is the dynamic movement of migration flows (in particular those Albanian) ${ }^{2}$.

The report presents information on the implementation of 93 articles of the UN Convention, "On Protection of the Rights of All Migrant Workers and Members of Their Families" and the measures taken by the state authorities responsible of the development of legal, institutional and policy regarding the fulfillment of the obligations arising from the Convention for the period 2011-203.

The report contains information on the implementation of the provisions of the Convention, the Committee's recommendations on the Protection of All Migrant Workers and Members of Their Families, and is based on the closing remarks (December 2010). Important place in this report, occupies the progress achieved in the legal, institutional, policy, difficulties/ challenges to guaranteeing the rights of migrant workers and members of their families.

Also, IOM has published a study "Assessment for the Protection of the Rights of Migrant Workers in Albania", which was prepared within the framework of the project "Promotion of good employment opportunities and protection of migrant workers in Albania"4. In preparing the report were consulted international conventions on migrant workers, particularly the rights of women migrant workers and other issues related legislation and regulatory framework on migration in Albania. They met and discussed with several key players, individual interviews with stakeholders and immigrants in Albania 5 .

\section{Legislative measures in compliance with obligations of the Convention}

In the context of fulfillment of all obligations arising from being a member state to the Convention, our country has taken a series of legislative, economic and political measures, that for this category to be offered assistance and be guaranteed rights and fundamental freedoms, in the framework of obligations to the European Convention for the Protection of Human rights.

So, one of the legislative measures is the adoption of the Law on Foreigners ${ }^{6}$, which guarantees improvements related to social protection for the treatment of foreigners to prevent discrimination in the treatment of employees. In the area of integration of foreigners, provides design and implementation of the National Programme of Social Integration of foreigners by institutions. Also, the circle of rights of migrant workers is enlarged in terms of revoke and not on the cancellation of the residence permit for health reasons, inability to work after issuing residence permits, changes in the labor market or unemployment for a certain period 7 . The law provides that the revocation and cancellation of the residence permit and therefore, the removal from the territory to persons employed or self-employed does not apply to health reasons or disability after obtaining a residence permit, changing labor market or financial difficulties due to the interruption of work for a period specified by law.

\footnotetext{
${ }^{1}$ Article 73 of the UN Convention "On Protection of Rights of All Migrant Workers and Members of Their Families". Second periodical national report, submitted pursuant to Article 73 of the Convention for the Protection of All Migrant Workers and Members of Their Families (CMW), was developed in accordance with the instructions on the form and content of reports to be submitted by states parties, for the period 2011-2015.

${ }^{2}$ According to official data, about this situation, by the relevant state institutions are taking important measures of legal, institutional and practical to address them.

${ }^{3}$ Concretely, the report determine the definition of migrant workers, the rights and freedoms that should be guaranteed as a right to life, freedom of movement from the country of origin, the prohibition of torture, prohibition of forced labor, freedom of thought, conscience and religion as well as information on the recommendations of the Expert Committee after reviewing the first report of Albania in 2010.

4 This study was made possible through funding by the Government of the Kingdom of Sweden, through the Coherence Fund "One UN".

5 The full study can be read it in: http:/www.albania.iom.int/publications/reports/assessment of the protection of the rightsof migrant workers in Albania

${ }^{6}$ Law no.108/2013, "On Foreigners", as amended, approved on dated 28.3.2013 and published on Official Gazzete, no.48, pg.2111.

${ }^{7}$ Article 41 and 42, paragraphs 3,4 and 5 .
} 
In National Strategy for Employment and Skills 2014-20201 are including labor migration policy for 2014-2020. The measures of the action plan of this strategy contribute directly or indirectly to guarantee protection from various forms of discrimination.

Another one law that provides protection for migrant workers is the law on Emigration of Albanian Citizens for employment purposes $^{2}$, which stipulates the establishment and functioning of counters migration, which provide information for Albanian citizens who wish to emigrate, as well as support for reintegration returning migrants.

\section{The obligations arising from bilateral agreement in this field}

Our country has signed several bilateral agreements, through which guaranteed the provision of mutual assistance to employment for migrating to different countries.

So, in April 2014 it signed an agreement with the State of Qatar, between the Government of the Republic of Albania and the Government of the State of Qatar regarding the regulation of employment of citizens of the Republic of Albania in the State of Qatar. The employment agreement with Qatar aims at defining the rules and regulations of employment of Albanian citizens will be employed in the State of Qatar ${ }^{3}$.

Agreement in Article 9 provides that the terms and conditions of employment of the worker in the State of Qatar defined by an individual employment contract concluded between the employer and the employee. The individual contract contains the main work conditions, and the rights and duties of the parties, which are in accordance with the provisions of the agreement and labor law of the State of Qatar ${ }^{4}$.

In May 2012, with the German Party was signed memorandum of understanding on cooperation in the framework of pilot project "Triple Win Migration" 5 . The main purpose of the pilot project is to reconcile the divergent interests of the German labour market, the home countries and the workers themselves so that everyone benefits. For the skilled workers, labour migration is an opportunity for personal and professional development. Many of them take their new-found skills back home later, thus benefiting their country of origin. In home countries with high unemployment, the scheme helps to ease the pressure in the labour markets and boosts the economy, as labour migrants generally send money back home to support their families. And German employers gain access to well-qualified staff.

\section{Defensive measures within a social benefit - contributions from social and health insurances}

In accordance with international experience in the field of social protection, protection of migrants is regulated through adherence to international legal instruments in the field of social protection, signing of bilateral agreements between the respective countries, as well as national legislation.

Rules for the coordination of social security schemes to employed persons, self-employed persons and members of their families who move within the community are defined in Council Regulation Nr. 1408 / 71 and Regulation Nr. 883 / 2004 of the European Parliament and the European Council.

\footnotetext{
${ }_{1}^{1}$ Approved with decision no.818, dated 26.11.2014, of Council of Ministers, "On approvement of National Strategy for Employment and Skills 2014-2020".

2 Law no.9668, dated 18.12.2006 "On emigration of Albanian Citizens for employment purposes", as amended with law no.10389, date 3.3.2011.

${ }^{3}$ In the text of the agreement is set out in a detailed way procedures to be followed by the Ministry of Labour and Social Affairs of the State of Qatar, for the submission of applications for recruitment by employers of this state, determining the employer shall take all the necessary procedures for the selection of workers and their journey to the State of Qatar. Also, the government of the State of Qatar will take over the prosecution of restoration procedures Albanian workers when their contract work is completed.

4 The contract specified the details of that employer obligations related to employee housing, salary, medical treatment etc.

5 With the Triple Win Pilot Project, the Federal Employment Agency's International Placement Services (ZAV) and GIZ have jointly developed new, sustainable and effective approaches to recruiting foreign skilled ëorkers for the German labour market in response to German demographic trends. Under the pilot scheme, applicants from countries outside the EU are recruited to fill vacancies in German companies. This form of labour migration complements domestic labour market measures such as improving training, raising the retirement age, and increasing the percentage of ëomen in employment.In the recruitment of skilled workers from countries outside the European Union, the Triple Win Pilot Project focuses on the interests of German companies, foreign skilled workers, and the countries of origin benefiting all three groups.
} 
Our country has guaranteed and continues to guarantee, through the improvement of the legal framework, protection of foreign nationals and stateless persons, who work in Albania. In this sense, the Government has adopted a number of bilateral agreements with EU countries and not only in the field of social protection ${ }^{1}$.

These agreements consist of the provision of social security benefits and is based on the principle of equal treatment of workers in employment, dealing with benefits and income. Also, coordination rules ensure that persons moving from one country to another and their dependents and survivors preserve the rights acquired or are being acquired. Union of periods provided under the various national legislations will be taken into consideration to ensure the right to benefits and their calculation.

The object of these agreements are the benefits from the Albanian scheme of mandatory social insurance, which include specifically mandatory social insurance for pensions, work accidents, occupational diseases, maternity and sickness, and about the other party, the benefits associated with benefits for health insurance, accident insurance and pension insurance, etc. The parties have agreed to give these benefits based on their respective social security legislation.

It is currently in process of approval of the decision of the Stabilisation and Association Council on the coordination of social security schemes between the Republic of Albania and the EU, pursuant to Article 48 of the SAA.

\section{Protective measures in the fight against human trafficking}

New Action Plan for Social and Economic Reintegration of women and girls victims of trafficking ${ }^{2}$, helps in socio-economic development of women and girls VT / VMT in the field of economic empowerment, such property rights, employment and vocational training, housing, education and social care. In this context, the function is set and the state authority responsible for the identification, referral, protection and reintegration of victims / potential victims of trafficking. This authority on the foundation of his work has the harmonization of the existing legal framework in practice and international experience, which provide mechanisms to monitor the situation of migrant female, including those employed as domestic, with national practices in order to obtain protective measures and providing appropriate guarantees that protect these categories of exploitation and violence

\section{Conclusions}

Nationals of one of the member countries of the European Union and the Schengen area, who are legally resident in the Republic of Albania enjoy the right to employment as well as Albanian citizens, they didn't granted the employment permit or registration certificate ${ }^{3}$.

The employer has a legal obligation to guarantee employees the principle of equal treatment with regard to the salary and other working terms and conditions of employment, social security, the right to health care, minimum and maximum duration defined working hours, duration annual leave pay, minimum salary, including rising salary for overtime, health and safety, safeguards for the work of pregnant women, women who have recently given birth or breastfeeding, as well as minors, ban discrimination, etc.

The child's right of a migrant worker to have the name, registration of birth and nationality, access to education on the basis of equal treatment, respect for cultural identity of migrant workers and their family, should be to the attention of state

\footnotetext{
${ }^{1}$ Agreement between the Republic of Albania and the Republic of Turkey, for social protection, which entered into force in 2015 . The cooperation with Belgium government in the field of social protection is finalized with the approval of the Law No.35/2014 and, agreement has entered into force in January 2016. Cooperation with Macedonia for social protection agreement, adopted by the Council of Ministers decision No.228. dated 3.11.2015, of the Council of Ministers and was signed in Skopje on March 17, 2015, from ministers social issues counterparts. The agreement with the Grand Duchy of Luxembourg. was ratified by the Parliament of the Republic of Albania, Law no.42 / 2015, dated 16.04.2015. The agreement with Hungary was approved with the decision nr.531, dated 06.08.2014, of the Council of Ministers and was signed in Tirana on 10.12.2014. Currently, this agreement is in the legislative procedure for ratification. Signing of the agreement on social protection between the Republic of Albania and Romania took place in Bucharest, on February 27, 2015, between the ministers of social affairs counterparts. Currently, this agreement is in the legislative procedure for ratification by the Assembly of the Republic of Albania. Other arrangements could be: with Canada, the Czech Republic (approved by the decision of CoM).

${ }^{2}$ Approved with decision no.115, dated 17.2.2016, of Council of Ministers.

${ }^{3}$ Articles 25, 27, 28: Principle of equality of treatment in respect of: remuneration and other conditions of work and terms of employment; social security; and right to receive urgent medical care.
} 
authorities responsible. So, the main laws and bylaws drawn up by education institutions in the Republic of Albania and to serve the education and integration of children of migrant workers, with a focus on providing and improving opportunities and services related to legal aspects and political have related to education and the right to education ${ }^{1}$.

Also, public institutions should cooperate, based on their competencies, with social partners, non-governmental organizations and international organizations for the promotion and implementation of programs of integration of foreigners into society. In all the activities exercised, public institutions and NGOs provide foreigners with protection against any form of discrimination. As above, it recommended increased efforts by the State party to combat smuggling of migration, especially of women and children, making the necessary steps to detect the illegal movement or clandestine migrant workers and their families and bringing them to justice.

\section{Bibliography:}

[1] The Constitution of Republic of Albania, approved by law no. 8417, dated 21. 10. 1998, as amended

[2] The Law no. 9320, dated 25. 11. 2004, Convention of the International Labour Organization (ILO) No. 97 , "Migration for Employment"

[3] The Law no. 9555, dated 8. 6. 2006, Convention no. 143 "For migrant workers (additional provisions) in 1975", as well as the Council of Europe Convention "On Legal Status of Migrant Workers

[4] The Law no. 9703, dated 2. 4. 2007, the UN Convention for the Protection of the Rights of All Migrant Workers and Members of Their Families

[5] The Law no. 108/2013, "On Foreigners", as amended, approved on dated 28. 3. 2013

[6] The Law no. 9668, dated 18. 12. 2006 "On emigration of Albanian Citizens for employment purposes", as amended with law no. 10389, date 3. 3. 2011.

[7] The Law no. 69/2012 "On system of preliminary education in Republic of Albania"

[8] The Law no. 7995, dated 20. 9. 1995, "For the promotion of employment", as amended.

[9] The decision no. 818, dated 26. 11. 2014, of Council of Ministers, "On approvement of National Strategy for Employment and Skills 2014-2020".

[10] The decision no. 115, dated 17. 2. 2016, of Council of Ministers.

[11] The decision no. 115, dated 17. 2. 2016, of Council of Ministers "On approving of National Action Plan of economic and social re-integrationof women and girls, victims of trafficking".

Links:

[1] www. kryeministria. al

[2] http:/www. albania. iom. int/publications/reports/assessment of the protection of the rightsof migrant workers in Albania

\footnotetext{
1 Articles 29, 30, 31 of the Convention: Right of a child of a migrant worker to a name, registration of birth and nationality; access to education on the basis of equality of treatment; respect for the cultural identity of migrant workers and members of their families. 